\title{
Application of the Markov Process to Evaluate the Reliability of a Complex Thermal Power System
}

\author{
ZDRAVKO M. MILOVANOVIĆ, University of Banja Luka, \\ Original scientfic paper \\ Faculty of Mechanical Engineering, Banja Luka \\ UDC: 621.1 \\ Republic of Srpska \\ DOI: 10.5937/tehnika2104477M
}

VALENTINA Z. JANIĆIĆ MILOVANOVIĆ, independent reseracher,

Banja Luka, Republic fo Srpska

DEJAN LJ. BRANKOVIĆ, University of Banja Luka,

Faculty of Mechanical Engineering, Banja Luka

Republic of Srpska

\begin{abstract}
Determining the reliability of a thermal power plant as a whole or in its individual components often requires long and very expensive tests under special operating modes on a very large number of samples or gathering the required exploitation data, which is even more difficult because of the choice of a general mathematical method (different forms of curves which quantitatively define reliability with different failure density functions and the high dependence of such curves on changes in the operating modes of components and environmental conditions). The introduction of approximate calculations, in order to overcome these problems, gives an insight into the basic reliability characteristics of the observed system as a whole, but also insufficiently exact final parameters, due to a whole series of larger or smaller approximations, as well as the inability to take into account all existing influences (development of new technologies, specifics newly developed disorders, etc.). Calculating the reliability of a complex system is only the first initial phase of verifying quantitative characteristics, that is, the hypothesis itself that we have more or less confidence in. Their final acceptance or rejection is a verification of reliability through the control of certain quantitative system indicators for the given technical conditions of operation. For these reasons, alternative terms are often used to verify reliability in the literature, such as reliability control or hypothesis testing. Designing a reliability model, through the application of simulation methods, to select the best parameters for the functioning of components and systems as a whole, in technological terms, should be supported by appropriate experimental methods (using collected data and stored data from the past). This paper provides an analysis of the application of the Markov process to assess the reliability of a complex thermal power system, with the aim of scheduling appropriate decisions on maintenance actions based on the required level of reliability. The optimum timing of replacement / repair of parts of a complex thermal power system is defined before its failure or the need to act correctively. Also, these models serve to provide a level of reliability by carrying out adequate maintenance actions on complex units within the thermal power plant.
\end{abstract}

Key words: thermal power plant, reliability assessment, Markov models, maintenance

\section{INTRODUCTION}

Thermal power plants are characterized by their

Author's address: Zdravko Milovanović, University of Banja Luka, Faculty of Mechanical Engineering, Banja Luka, Bulevar vojvode Stepe Stepanovića 71, Republic of Srpska

e-mail: zdravko.milovanovic@unibl.rs

Paper received: 18.11.2020.

Paper accepted: 14.07.2021. complexity, whether considering only the technological scheme or the installed equipment. Their exploitation provides the necessary electricity for the operation of the economy and the normal life of the inhabitants of the country.

On the other hand, large energy facilities with new or improved solutions can only be built if they have a high degree of security and reliability. In order to reduce maintenance costs and optimize the main-tenance strategy for thermal power plants, it is important to realize and understand the reliability and consequences 
of failures, as well as other factors that affect maintenance and production. Understanding reliabi-lity, however, is central to this process. [1]. In addition to estimation, data for determining reliability can be obtained through calculation and ve-rification, or naturally (unforced), through customer experiences, own production and other experiences, and through data from relevant service organizations engaged in main-tenance. If the object under con-sideration is complex (e.g., a thermal power plant sy-stem), then the problem of determining reliability is solved if the reliability of the constituent components, their interconnection (structure) and operating con-ditions (constraints and environmental conditions) are known.

Reliability can be defined as the ability of a system to perform the required function under the specified conditions for a given period of time. [2] Reliability is usually determined by the likelihood that the system does not cancel over a period of time $(0, t]$. The most direct way to express the properties of mindfulness is the reliability function $R(t)$, also called the existence (survival) function. [3] Other function which is used to express the reliability of the system is a function of the failure distribution $F(t)$ or a function of the failure density $f(t)$.

The term failure means that the system or component of the failing system does not fulfill the function of the purpose for which it was designed. There are distinguishable repairable and irreparable technical systems. The system can be defined as repairable, when it is possible to replace the damaged part and as irreparable, when it is not allowed to replace the failed element. For repairable systems, maintenance may be performed at a specified time interval [4].

Models and techniques for assessing and analyzing reliability can be divided into mathematical and conceptual [5]. Analytical models relate to repairable systems. Repairable systems are usually defined as those that will be repaired to restore their functions after each failure before being discarded during continuous operation [6]. A complex system typically indicates that it is composed of multiple components that can be connected in series or in parallel or in other complex ways.

Markov's (also called Markof) process is named after Russian mathematician Andrei Markov, who introduced it in 1907. This process describes the future state of the system based on present parameters and thus makes the past and future state of the system to be independent. When it is not about con- tinuous but discrete sizes then we can talk about Markov chains. Markov processes are suitable for assessing the reliability of functionally complex systems and complex repair or maintenance strategies. However, they imitate the monotony of functions and processes.

A model based on the Markov process assumes that the system has a finite state space and a series of possible transitions between these states [7]. Functions, diffe-rent failure models and standby and different main-tenance activities can be described as different states. If the transition between states can be approximated by stochastic processes on the properties of this model, then Ma-rkov methods can be used to evaluate the reliability of the system after several states. Thus, it is quite common to use Markov theory to model the relia-bility prediction problem of a repairable system [8]. Although the Markov method is often applied to repairable systems, it should be noted that it is not easy to arrive at the probabilities of all the transitio-ns required, and the model assumptions are alwa-ys very restrictive. Also, in the domain of continu-ous sizes i.e., Markov processes mathematical so-lutions of equations can be very inaccessible, which makes the applicability of the model as in many other cases seriously questionable.

\section{THERMAL POWER SYSTEM AS A COMPLEX TECHNICAL SYSTEM}

One of the basic tasks for assessing the reliability of a particular system is specifying the failure process of the elements or the most critical part of the plant, defining their configuration, modes and defining possible states that represent system failures. Assu-ming that at some point in time the system is in one of a finite number of states and that the elements in it cancel according to the law of exponential distribution, the use of this theory to estimate the reliability of the system is based solely on the previous state [9].

The thermal power plant system today is characterized by great complexity, with the presence of a wide range of many different technologies (mechanical engineering, energy, electronics, chemistry, etc.), figure 1.

By making certain assumptions, introducing technical diagnostics and maintenance according to the state and forming an appropriate database through organized collection of the failure data and their analysis using a wide range of statistical methods, the estimated values of the reliability indicators for a complex thermal power plant system can be obtained [10]. 


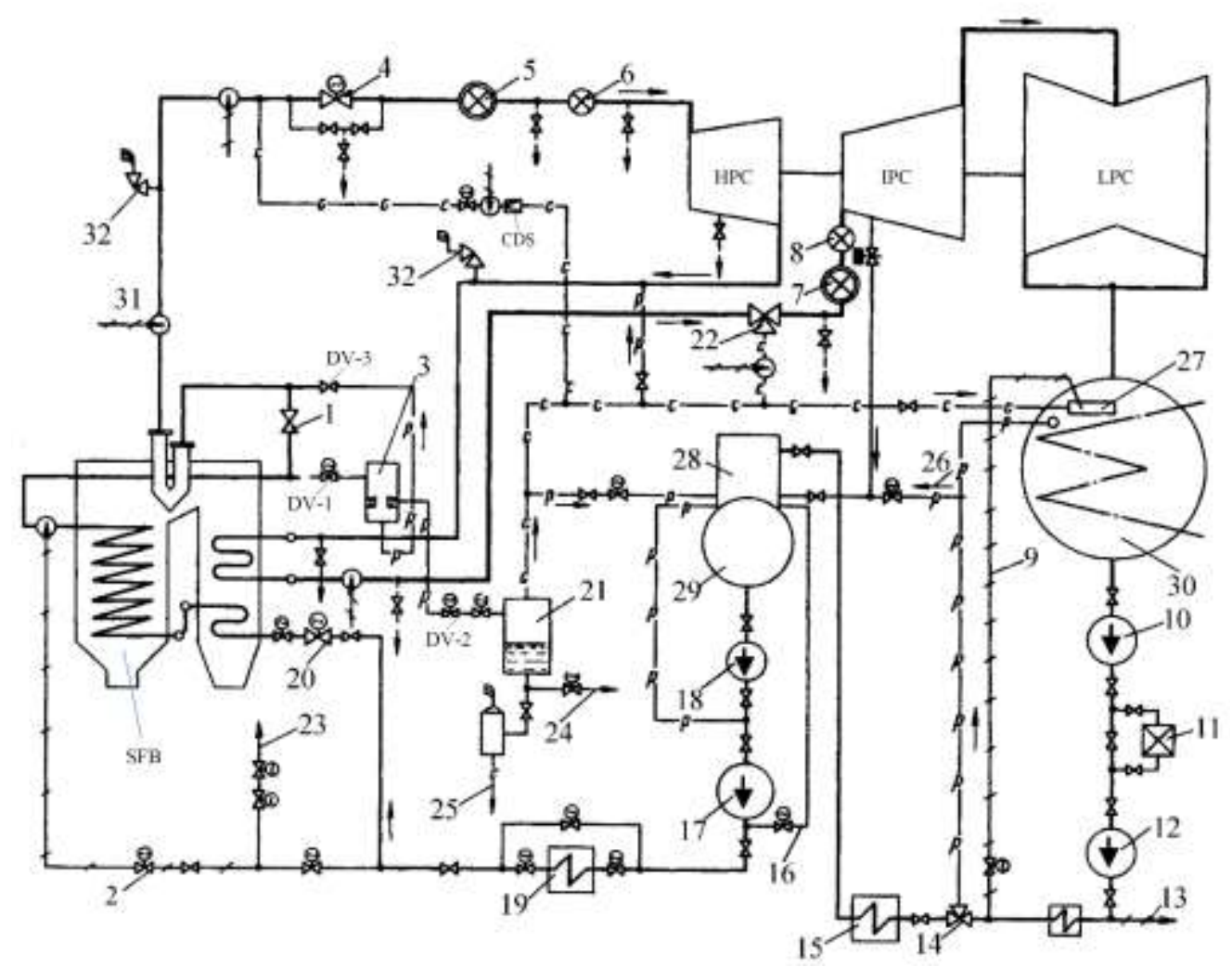

Figure 1 - View of a complex thermal power plant system [10]. Legend with Figure 1: 1 - start shutter; 2 control valve for injection of water in steam coolers; 3 - built-in start separator; 4 - main steam shutter (MSS); 5 - stop valve HPC; 6 - control valve HPC; 7, 8 - stop and control valves IPC or combined stopregulating valve IPC; 9 - line of injection of condensate into the steam-receiving capacitor device; 10 condensate pump I degree; 11 - ion exchangers for purification of turbine condensate; 12 - 2nd stage condensate pump; 13 - condensate drainage system BRRS; 14 - condensate recirculation valve; 15 - low pressure heating group (LPP); 16 - line of recirculation of supply water in water tank (WT); 17 - a supply pump; 18 - pre-pump or buster pump; 19 - high pressure heating group (HPP); 20 - control supply valve (supply head); 21 - Starting expander; 22 - a quick-acting vacuum valve for releasing steam from the inter overheating system to the condenser; 23 - return of excess water to the deaerator; 24 - discharge of condensate from the starting expander into the deaerator; 25 - discharge of condensate from the starting expander, alternatively: into the neutralizing basin of contaminated water, or to the cooling conduit or the reserve condensate tank; 26 - the supply of steam from a foreign source: a joint station for the distribution of low pressure steam, an auxiliary boiler room or a near block in operation; 27 steam-receiving device in the condenser; 28 - deaerator; 29 - a water tank (WT); 30 - turbine condenser; 31 - injecting a refrigerator of fresh steam; 32 - manuel control; $D V-1 \div D V$-3 - damping valves on the old appliance

The change of the state of the system takes place continuously over time, with a noticeable distinction between the states and a jumping transition. In this case, the system can be described by processes of Markov with discrete states, which is time continuous and homogeneous. Markov processes also include states with non-exponential distribution, since in these cases this is replaced by a combination of fictitious states with exponential distribution. The application of Markov and semi-Markov processes is possible through the introduction of certain simplifications related to the starting properties of the system under consideration, partly also the form of failures, their interrelation with planned overhauls, repairs (-) and with the long-term dynamics of the system exploitation as a whole.

As a rule, for the early stages of the life cycle, there are no data on the intensity of transitions between individual states of the system and on their time dependence, so the calculation of the reliability indicators and their estimation goes into the rank of expert or simulation estimates for certain interval ratings. Starting from the assumption that electricity produ-ction is not always maximal, but often due to the existence of various interruptions or failures, the need for maintenance, as well as some "higher" conditions, the 
thermal power plant is stopped and there is no electricity production. All possible stops can be divided into planned and unplanned. The failure of the thermal power plant is taken as a fact regardless of the mechanism of the failure.

\section{PROBABILITY EQUATIONS OF SYSTEM STATE AND SOLVING THOSE EQUATIONS}

In the case where the considered system has an arbitrary but limited number of states, the probability of the state of the system is determined from the Kolmogorov equations

$$
\begin{aligned}
& p_{k}^{\prime}(t)=\sum_{i=1}^{k-1} a_{k i} \cdot p_{i}(t)+a_{k k} \cdot p_{k}(t)+ \\
& +\sum_{i=k+1}^{n} a_{k i} \cdot p_{i}(t) ; \quad k=1,2, \ldots, n,
\end{aligned}
$$

where: $p_{k}(t)$ - is the likelihood that the system at the moment of $t$ will in state of $k$, where for $k=1$ the first term in equation (1) equals zero; $n$ - is number of system states; $a_{k i}$ - intensity of transition from $i$ state to $k$ state, $k \neq 1 ; a_{i i}$ - the intensity of leaving the $i$ state with a negative sign.

The intensity of leaving state is equal to the sum of the intensity of the transition from the state to the other states of the system, so it is:

$$
a_{i i}=-\sum_{\substack{k=1 \\ k \neq 1}}^{n} a_{k i}
$$

If the system has $m$ components, the total number of possible states of the system is determined by the relation

$$
n \leq \prod_{j=1}^{m} n_{j}
$$

where the number of possible states of the component $j$ is marked with $n_{j}$.

Equation (1) can also be written in matrix form

$$
p^{\prime}(t)=a \cdot p(t)
$$

where are:

$$
\begin{aligned}
& p(t) \equiv\left[p_{1}(t) \ldots p_{n}(t)\right]^{T} ; \\
& a \equiv\left[\begin{array}{l}
a_{11} \ldots a_{1 n} \\
\ldots \ldots \ldots \ldots \\
\ldots \ldots \ldots \ldots \\
a_{n 1} \ldots a_{n n}
\end{array}\right] .
\end{aligned}
$$

The system state probability is obtained by solving differential equations (4) for known initial conditions $p_{k}(0) ; k=1,2, \ldots, n$. Equations can be solved in many ways, the most common of which are: solving equations using known numerical methods for integrating systems of differential equations, and analytically, using the Laplace transform, the way many differential equations are solved analytically.

Starting from Equation (4) it is not difficult to show that it is valid

$$
s \cdot p(s)-p(0)=a \cdot p(s)
$$

respectively

$$
p(s)=\left(I_{n} \cdot s-a\right)^{-1} \cdot p(0)
$$

where: $p(s)$ - is Laplace transform $p(t)$, with the $s$ operator of this transformation; $I_{n}$ - unit diagonal matrix of dimensions $n \times n$.

The required solutions are obtained by inversion of according to the previously given expression. It should also be noted that approximate solutions are considered satisfactory for some analyzes. The correct solution can be represented in the form of an expression

$$
p(t)=\exp (a \cdot t) \cdot p(0)
$$

For small parameter values, $t$ expression (8) can be replaced by an appropriate potential row with finite number of terms

$$
\begin{aligned}
& p(t)=\left[\sum_{k=0}^{q} a^{k} \cdot \frac{t^{k}}{k !}\right] \cdot p(0) ; \\
& a^{0}=I_{n} .
\end{aligned}
$$

where with $q$ is made evaluation based on the relative value of the last member of the row relative to the sum of the previous members.

If, however, a time discretization is performed at an interval significant for analysis, a time increment $\Delta t$ is introduced, for which the following applies

$$
p(\Delta t) \approx\left(I_{n}+a \cdot \Delta t\right) \cdot p(0)
$$

that is, generally

$$
\begin{aligned}
& p(k \cdot \Delta t) \approx \\
& \approx\left(I_{n}+a \cdot \Delta t\right) \cdot p((k-1) \cdot \Delta t) .
\end{aligned}
$$

\subsection{Compilation of equations for system state probabilities based on component equations}

An easy way to form equations for the state probabilities of a complex system, if the equations of state of its components are known, is to use Kronecker's algebra. In doing so, the following facts should be borne in mind: 
- Kronecker product of matrix $A$ of dimension $m \times n$ and matrix $B$ of dimension $p \times q$, represents matrix with dimensions $(m \cdot p) \times(n \cdot q)$;

- The Kronecker sum of squares of a matrix $Q$ with dimensions $q \times q$ and a square matrix $M$ with dimensions $m \times m$ is a square matrix of dimensions $(q \times m) \cdot(n \cdot q)$.

If the observed system has components with transition intensity matrices $a_{i} ; i=1,2, \ldots, n$ if the components of the system are independent of each other in terms of the transition to different states, that is, independent of the state in which the other components of the system are located, the system transition intensity matrix can be calculated as the Kronecker sum of matrices, which can be displayed as

$$
a=\bigoplus_{i=1}^{n} a_{i} .
$$

If the event of component residence is indicated with and in state, a vector of possible component state-events can be considered

$$
s_{i}=\left[s_{i 1} s_{i 2} \ldots s_{i n_{i}}\right]^{T}
$$

here $n_{i}$ is a number of possible states of the component.

The vector of possible event - state of the system is obtained by the Kronecker product of the vector $s_{i}$, for components, which is denoted as

$$
s=\bigoplus_{i=1}^{n} s_{i},
$$

In this case, the order of the system components in equation (14) should be the same as in equation (12). System state probabilities are the probabilities of events that are an integral part of the vector elements, which can be formally written by the following equation

$$
p(t)=p\{s\}
$$

For a more detailed analysis of the use of Markov processes and semi-Markov processes, it is necessary to consider the possible variants of the elements of the system, in relation to the number of possible states of the system, which need to be adopted in more detail and earlier.

\section{APPLICATION OF THE MARKOV METHOD TO THE REFERENCE BLOCK OF A $300 \mathrm{MW}$ POWER PLANT SYSTEM}

To analyze the operation of a thermal power plant Markov model can be used. Based on the assumption of the Markov process certainty, if the initial state and the probability of transition between them are known, the thermal power plant in this process is defined as one element with six possible states: condition IN OPERATION, planned shutdown due to suitable power situation, planned shutdown due to regular overhaul and unplanned shutdowns due to boiler fail-ure, turbine and failure of other drive elements, figure 2. On the other hand, system availability is defined as the possibility of system operation for a longer period of time, that is, the sum of the probability of state IN OPERATION and shutdown status due to a suitable power situation.

The Markov process defined in this way can be written with a system of six linear differential equations [10]:

a) for the state IN OPERATION:

$$
\begin{aligned}
& \frac{d P S_{0}(t)}{d t}= \\
& =\sum_{i=1}^{5} \mu_{i} \cdot P S_{i}(t)-P S_{0}(t) \cdot \sum_{i=1}^{5} \lambda_{i},
\end{aligned}
$$

b) for the state IN OPERATION:

$$
\begin{aligned}
& \frac{d P S_{i}(t)}{d t}= \\
& =\lambda_{i} \cdot P S_{0}(t)-\mu_{i} \cdot P S_{i}(t),
\end{aligned}
$$

where: $P S_{i}(t)$ - the probability that the system in time $t$ will be in a state $S_{i}, \lambda_{i}$ - the likelihood of switching from the IN OPERATION state to the stop state, and $\mu_{i}$ - the probability of switching from a stop state to IN OPERATION state.

With the introduction of boundary conditions, the thermal power plant in a moment is in state IN OPARATION, in this transformed system we get some particular solution, which we have to inverse yet, in order for the final solution of the Markov process to represent the time dependence of the probability of the state, which takes the form:

$$
P S_{i}(t)=c_{i 1}+\sum_{j} c_{i j} \cdot e^{p_{i j}^{t}}
$$

where: $c_{i j}$ - partial fracture coefficients, $p_{i j}$ - zeros of polynomials, and $i, j$ - condition index and time index.

All necessary probabilities of switching between states were obtained on the basis of statistical processing of data on the ten-year operation of the power plant, where time is most often expressed in days. It can be observed that the solution given by equation (18) has members that are time independent and members whose value decreases exponentially with time. As the system of a thermal power plant can be in 
only one state, then the sum of the probabilities of all states at any moment must be equal to number one, that is:

$$
\sum_{i} P S_{i}(t)=1
$$

Reliability $R$ is the probability that the system will perform the task at a given time, while unreliability $F$ is the probability that the system will not perform the task at a given time.

The Markov process can also be generalized to states, with the appearance of certain problems when looking for the zero of that polynomial which is of $n+1$ order. It is also applicable to the search for long-term reliability, that is, unreliability.

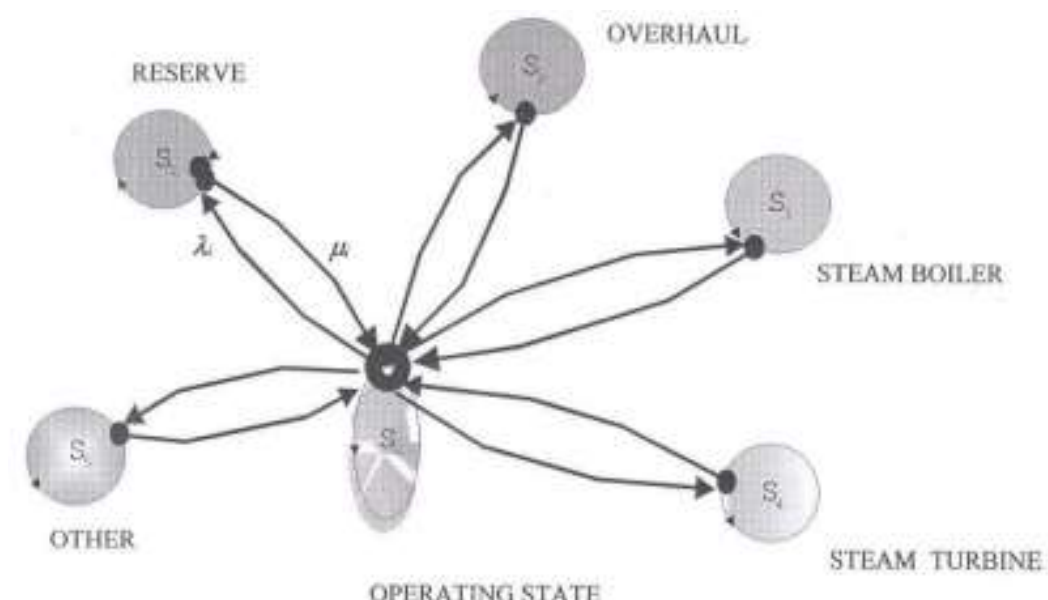

Figure 2 - Schematic view of transition of the thermal power plant system from OPERATION state to stop state [10]

Long-term reliability $R_{\infty}$ i.e., long-term unreliability $F_{\infty}$,was obtained by observing the technical system of the thermal power plant over a long period of time: $F_{\infty}\left(s_{i}\right)=$ (sum of time intervals in condition $\left.S_{i}\right) /($ total observation time );

$$
R_{\infty}+\sum_{i} F_{\infty}\left(s_{i}\right)=1
$$

The probability of transition $z$ from state $S_{i}$ to state $S_{i \pm 1}$ is defined as the conditional probability, that is, the system will stop working at a time interval $(t, t \pm \Delta t)$, if it worked at an instant $t$.

For these reasons, through the processing of data from at least ten years of observation of the operation of the thermal power plant system, it is necessary to determine the distribution of transition $z$ probability events, where there is $t \succ 0$. The resulting distribution should also be tested by some of the known tests.

On the other hand, the Markov process in figure 2 can be generalized to $n$ states, with a similar regularity that the transition between states is possible only through states $S_{0}$, figure 3 .

In the case of expression for long-term reliability or long-term uncertainty, the factors $c_{i j}$ in equation (18) should be determined as follows:

$$
\begin{aligned}
& R_{\infty}=c_{01}=\frac{\prod_{i=1}^{n} \mu_{i}}{\prod_{i=1}^{n} \mu_{i}+\sum_{i=1}^{n} \lambda_{i} \prod_{j=1}^{n} \mu_{j}} \\
& F_{\infty}\left(s_{i}\right)=c_{i 1}=R_{\infty} \cdot \frac{\lambda_{i}}{\mu_{i}}
\end{aligned}
$$

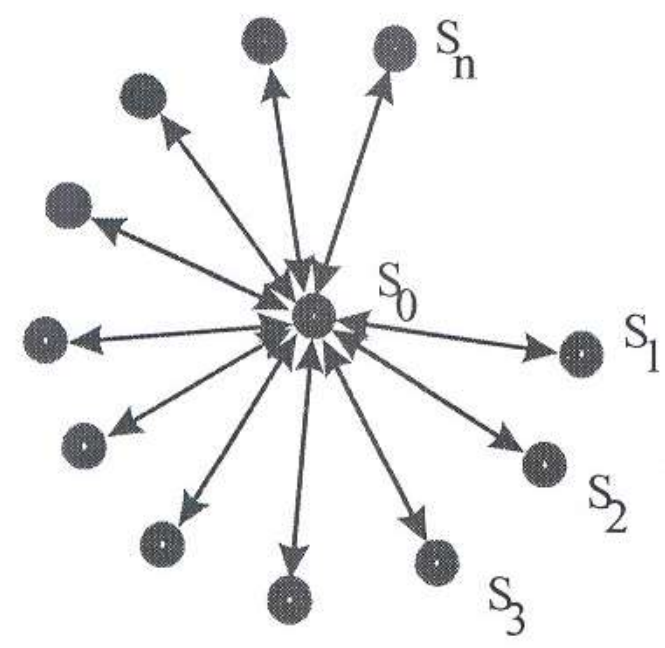

Figure 3 - Generalization of the Markov process to states [10]

It is not difficult to conclude that long-term reliabilities depend only on transition probabilities $\mu_{i}, \lambda_{i}$. 


\subsection{Short-term forecast of reliability characteristics}

The considered six states of the thermal power plant system can be represented by the Markov process with the system of six linear differential equations (16) and (17), which can be transformed into a system of linear equations by Laplace transform. By introducing boundary conditions into this tra-nsformed system in the form of the formulation that the system of a thermal power plant is in a state IN OPE-RATION in an instant, $t=0$ a particular solution is obtained, which still needs to be transformed.

In this case, the final solution of the Markov process is the time dependence of the probability of the state, which after the inverse transformation takes the form of the equation given by (18). All required transition proba-bilities are obtained from statistical data processing for at least ten years of operation of the plant.
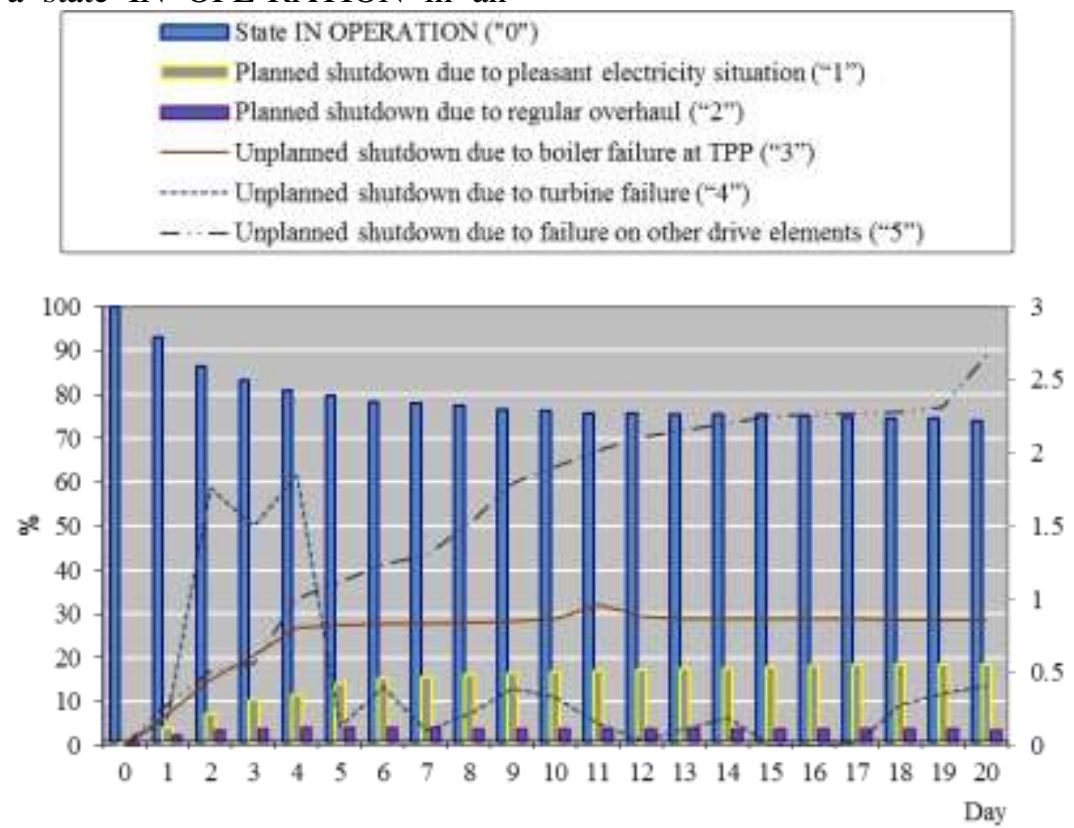

Figure 4 - Reliability characteristics of the Šoštanj TPP 253 MW as a function of time
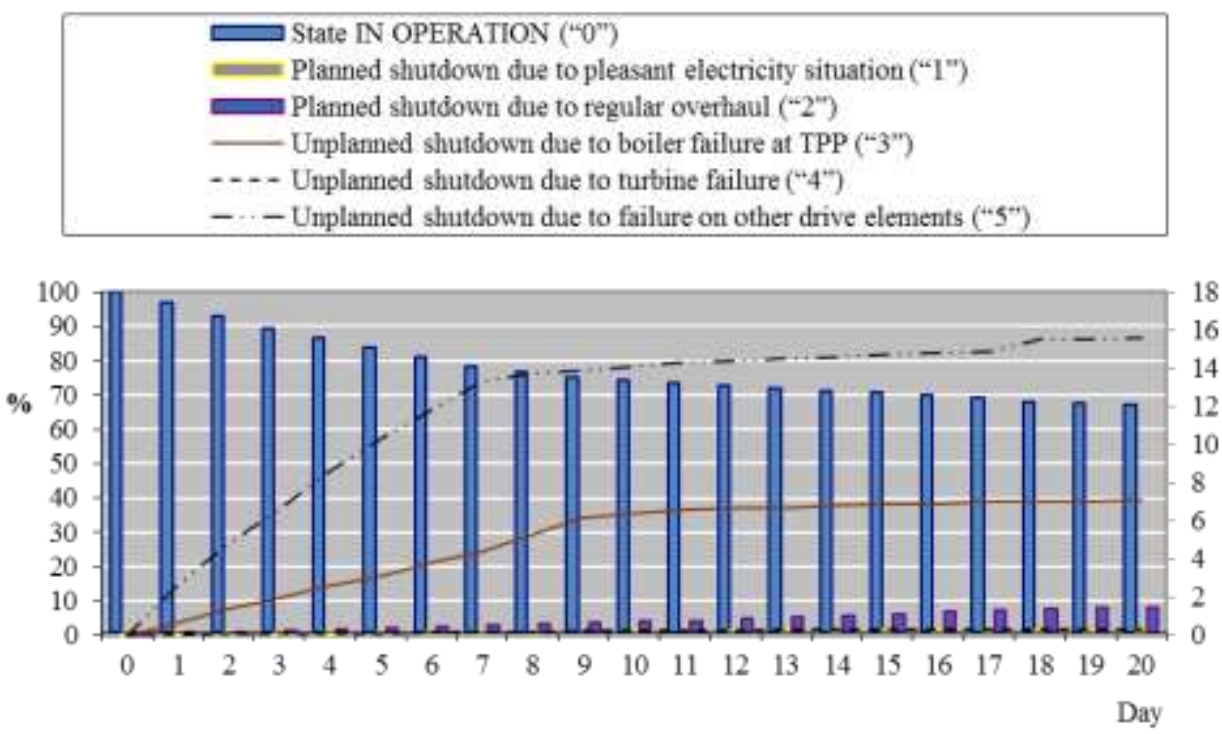

Figure 5 - Reliability characteristics of the TPP Carbon Power of 300 MW as a function of time

Figure 4 gives a graphical representation of the obtained results of the reliability characteristics for the operation of the Šoštanj power plant of 253 MW. Similarly, analogous curves were obtained for a system of 300 MW Ugljevik thermal power plants, figure 5. The curve, indicated on the graph by "0", repre-sents a graphical interpretation of the time flow of sy-stem reliability, while the other curves represent the time 
course of stopping probability $P S_{i}(t) ; i=1, \ldots, 5$ It should be noted that the reliability of the system after startup is rapidly decreasing, to stabilize after approximately $8 \div 10$ days to values of approximately $75 \%$ for TPP Šoštanj and $65 \%$ for the Ugljevik thermal power plant.

By analyzing the data on the ten-year operation of the Šoštanj TPP system, it was concluded that the events in the observed thermal power plant are subject to an exponential distribution law, defined with only one parameter - the transition probability $z$, in the form $R(t)=e^{-z \cdot t}$. In a similar way, the Weibull twoparameter distribution for the operation of the system resulted in a system of 300 MW Ugljevik thermal power plant in the form of the system of equations (10) $\div(14)$.

In the first case, the testing was performed with Pearson's $\chi^{2}$-test, while in the second case, the testing was performed with the Kolmogorov-Smirnov test. The transition probabilities for both power plants were determined analytically and graphically with probability paper.

\subsection{Long-term forecast of reliability characteristics}

Similarly, long-term reliability can be forecasted. As can be seen from figure 4 and figure 5 , all values $P S_{i}(t)$ approach an exponentially some asymptotic value, called long-term reliability or unreliability, which reaches in time $t=\infty$. It should be noted that some probabilities reach some maximum value and then fall slowly, which depends on the magnitude and the sign of the coefficients $c_{i j}$ in equation (17).

Table 1. Long-term reliability and unreliability for the system of TPP Šoštanj

\begin{tabular}{|l|l|l|l|}
\hline \multirow{2}{*}{ State } & \multicolumn{3}{|l|}{ TPP Šoštanj with a power of 294 MW } \\
\cline { 2 - 4 } & $\begin{array}{l}\text { Markov } \\
\text { process }\end{array}$ & $\begin{array}{l}\text { Statistical } \\
\text { analysis }\end{array}$ & $\Delta, \%$ \\
\hline$S_{0}$ & 0,775 & 0,839 & 8,258 \\
\hline$S_{I}$ & 0.068 & 0,045 & 33,823 \\
\hline$S_{2}$ & 0,099 & 0,067 & 32,323 \\
\hline$S_{3}$ & 0,046 & 0,039 & 15,217 \\
\hline$S_{4}$ & 0,007 & 0,006 & 14,286 \\
\hline$S_{I}$ & 0,002 & 0,002 & 0 \\
\hline
\end{tabular}

Table 1 and Table 2 compares the values obtained as a result of calculations with a Markov process with real long-term reliability or uncertainty, calculated on the basis of statistics over a long period of time, and based on the system of equations $(17) \div(20)$.
Table 2. Long-term reliability and unreliability for the system of TPP Ugljevik

\begin{tabular}{|l|l|l|l|}
\hline \multirow{2}{*}{ State } & \multicolumn{3}{|l|}{ TPP Ugljevik with a power of 300 MW } \\
\cline { 2 - 4 } & $\begin{array}{l}\text { Markov } \\
\text { process }\end{array}$ & $\begin{array}{l}\text { Statistical } \\
\text { analysis }\end{array}$ & $\begin{array}{l}\Delta, \\
\%\end{array}$ \\
\hline$S_{0}$ & 0,673 & 0,658 & 2,23 \\
\hline$S_{1}$ & 0,017 & 0,015 & 11,76 \\
\hline$S_{2}$ & 0,080 & 0,083 & 3,75 \\
\hline$S_{3}$ & 0,071 & 0,067 & 5,63 \\
\hline$S_{4}$ & 0,0035 & 0,003 & 14,28 \\
\hline$S_{1}$ & 0,156 & 0,174 & 11,54 \\
\hline
\end{tabular}

\section{ANALYSIS AND DISCUSSION OF RESULTS}

Analyzing the values given in table 1 and table 2, it can be seen that the results from these analyzes are relatively good for deviations for long-term reliability

$$
\Delta=\left|\begin{array}{l}
\left.R_{\infty}^{\text {stat }}\left(F_{\infty}^{\text {stat }}\right)-R_{\infty}^{\text {Mark }}\left(F_{\infty}^{\text {Mark }}\right)\right] \cdot 100 / \mid \\
/ R_{\infty}^{\text {stat }}\left(F_{\infty}^{\text {stat }}\right)
\end{array}\right|
$$

$(10 \%)$, while deviations for long-term uncertainty are significant $(10 \div 35 \%)$.

The most important part in the application of the Markov process is the likelihood of a transition from the IN OPERATION to the stop state at some time interval $(t, t+\Delta t)$, and vice versa. If this time interval is determined within some reasonable limits, the results are shown to be minimally dependent on the length of the time interval.

The obtained numerical results for the transition probability for the steam boiler, as the most critical element of the thermal power plant system, for the 300 MW reference block, show that generally boilers „,behave" very similarly ( $1 / \lambda=25 \pm 5$ days) with larger deviations occurring in examples with low realization probability.

If we compare the obtained values for reliability characteristics between TPP Šoštanj and TPP Ugljevik, it can be noticed that the thermal power plant system has a slightly lower reliability for the state IN OPERATION and planned shutdown due to the suitable power situation, but therefore significantly more other characteristics. Of course, this comparison should take into account the fact that the working conditions and the quality of the fuel used in the two facilities are not the same, and therefore the results of the comparison can be doubted.

\section{CONCLUSION}

The application of this type of process to a thermal power plant system with a complex program of unplanned repairs and routine technical maintenance gives results that deviate considerably from the stati- 
stical processing of data from actual exploitation (and over 30\%). For semi-Markov processes, which take into account the differences in the distribution of time from the first transition to a given state until the next transitions, the calculations are made for the modes of operation of steady state processes in the thermal power plant system, and therefore its initial state becomes irrelevant. The analytical solutions obtained for Markov processes and semi-Markov processes for the early stages of the lifetime of a thermal power plant, assuming an infinite period of exploitation, do not give the required accuracy of the solution for a finite lifetime or for a finite intermittent period. For these reasons, their application is limited to a forecast period of up to 30 days, or to a combination of estimation of reliability indicators with other methods (Weibull two-parameter model, FTA analysis, FMEA/FMECA analysis, etc.). The advantage of applying the Markov method during the exploitation of the thermal power plant system lies in the form of the result obtained, as a continuous time flow of reliability of the thermal power plant operation or a continuous time flow probability of failure of the thermal power plant, which ordinary methods do not give.

\section{REFERENCES}

[1] Lowry G, Factors affecting the success of building management system installations, Building Services Engineering Research and Technology, 23(1), 57-66, 2002.

[2] Hoyland A, Rausand M, System reliability Theory: Models and Statistical Methods, John Wiley \& Sons, Inc., New York, 1994.

[3] Cox D. R, Oakes D, Analysis of Survival Data, Chapman \& Hall, London, 1984.

[4] Milovanović Z, Modified Method for Reliability Evaluation of Condensation Thermal Electric Power Plant, Ph.D. thesis, University of Banja Luka, Faculty of Mechanical Engineering Banja Luka, Banja Luka, (in Serbian), 2000.
[5] Sun Y, Reliability Prediction of Complex Repairable Systems: An Engineering Approach, Thesis submitted in total fulfilment of requirements of the degree of Doctor of Philosophy, Faculty of Built Environment and Engineering, University of Technology, Queensland, 2006.

[6] Crow L. H, Reliability analysis for complex repa-irable systems, In: Proschan, F., Crow, L.H. (eds) Reliability and Biometry, Philadelphia, Pennsylvania: SIAM, pp. 379-410, 1974.

[7] Milošević A. D, Reliability Ensuring Models TI of Complex Facilities in Thermal Power Plants, Technical Faculty Mihajlo Pupin, Zrenjanin, Serbia, 2015.

[8] Fiems D, Steyaert B, Bruneel H, Analysis of a discretetime GI-G-1 queuing model subjected to burst interruptions, Computers \& Operations Research, 30(1), 139-153, 2003.

[9] Papić, Lj, Milovanović Z, Maintenance and reliability of technical systems, DQM monograph library Quality and reliability in practice, Book 3, Prijevor, (in Serbian), 2007.

[10]Milovanović Z, Optimization of Power Plant Reliability, University of Banja Luka, Faculty of Mechanical Engineering Banja Luka, Banja Luka, (in Serbian), 2003.

[11]Milovanović Z, Monographs: Energy and Process Plants, Tom 1: Thermal Power Plants - Theoretical Foundations, University of Banja Luka, Faculty of Mechanical Engineering Banja Luka, Banja Luka, (in Serbian), 2011.

[12]Milovanović Z, Monographs: Energy and Process Plants, Tom 2: Thermal Power Plants - Technolo-gical Systems, Design and Construction, Explo-ita-tion and Maintenance, University of Banja Luka, Fa-culty of Mechanical Engineering Banja Luka, Banja Luka, (in Serbian), 2011. 


\section{REZIME}

\section{PRIMJENA PROCESA MARKOVA ZA PROCJENU POUZDANOSTI SLOŽENOG TERMOENERGETSKOG SISTEMA}

Određivanje pouzdanosti termoenergetskog postrojenja u cjelini ili njegovih pojedinih komponenti, često zahtijeva obavljanje dugotrajnih i veoma skupih ispitivanja pod posebnim režimima rada na vrlo velikom broju uzoraka ili prikupljanje zahtijevanih podataka iz eksploatacije, što je još teže, iz razloga izbora generalne matematičke metode (različiti oblici krivulja koje kvantitativno definišu pouzdanost sa razlicitim funkcijama gustoće otkaza i velikom zavisnosti takvih krivulja od promjene režima rada komponenti i uslova okoline). Uvođenje aproksimativnih proračuna, radi prevazilaženja navedenih problema, daje uvid u osnovne karakteristike pouzdanosti posmatranog sistema u cjelini, ali i nedovoljno egzaktne krajnje parametre, usled čitavog niza većih ili manjih aproksimacija, kao i nemogućnosti uzimanja u obzir svih postojećih uticaja (razvoj novih tehnologija, specifičnosti novonastalih poremećaja $i d r$.). Proračun pouzdanosti složenog sistema predstavlja samo prvu početnu fazu verifikacije kvantitativnih obilježja, odnosno samu formiranu hipotezu u koju imamo više ili manje povjerenja. Njihovo konačno prihvatanje ili odbijanje predstavlja verifikaciju pouzdanosti kroz kontrolu određenih kvantitativnih pokazatelja sistema za zadane tehničke uslove rada. Iz tih razloga se često za verifikaciju pouzdanosti u literaturi koriste i alternativni pojmovi, kao što su kontrola pouzdanosti ili testiranje hipoteze. Izrada modela pouzdanosti kroz primenu metoda simulacije za izbor najboljih parametara funkcionisanja komponenata i sistema u cjelini, u tehnološkom smislu treba potkrijepiti odgovarajućim eksperimentalnim metodama (upotrebom sakupljenih podataka i pohranjenih podataka iz prošlosti). U okviru ovog rada daje se analiza primjene procesa Markova za procjenu pouzdanosti složenog termoenergetskog sistema, s ciljem terminiranja donošenja odgovarajućih odluka o akcijama održavanja na bazi potrebnog nivoa pouzdanosti. Definisanjem optimalnih vremenskih termina zamene/opravke delova složenog termoenergetskog tehničkog sistema pre nego što dođe do njegovog otkaza ili potreba da se deluje korektivno. Takođe, ovi modeli služe i za obezbjeđenje nivoa pouzdanosti sprovođenjem adekvatnih akcija održavanja na složenim cjelinama u okviru termoenbergetskog postrojenja.

Ključne riječi: termoenergetsko postrojenje, procjena pouzdanosti, modeli Markova, održavanje 